\title{
Product Brokering Efficiency as a mediator of Online Product Recommendation and Customer Loyalty
}

\author{
Felisia Lilian ${ }^{* 1}$, Honey Wahyuni Sugiharto Elgeka ${ }^{2}$, V Heru Hariyanto ${ }^{3}$ \\ ${ }^{1,2,3}$ Faculty Of Psychology, Universitas Surabaya
}

Submission 17 February 2021 Accepted 11 October 2021 Published 24 December 2021

\begin{abstract}
Marketing strategies in e-commerce have a main goal, that is to pursue customer loyalty. Sociolla is an e-commerce company that sells cosmetic products and has a recommendation feature to make it easier for customers during the shopping process. These recommendations can trigger customer satisfaction and generate loyalty. The purpose of this study was to examine the correlation between online product recommendation and customer loyalty with product brokering efficiency as a mediator. 179 Sociolla customers were recruited in this study using a convenience sampling. The data were analyzed using the SPSS - Process Hayes model 4. Results showed that perceived decision quality acts as a mediator in the relationship between enablers and customer loyalty $(\beta=.20,[.13 ; .27])$. It can be concluded that recommendations that are comprehensive, clear, and meet the customer needs will make it easier for customers to make purchasing decisions, which ultimately leads the customers to form loyalty toward the products.
\end{abstract}

Keywords: customer loyalty; online product recommendations; product brokering efficiency

Advance technological developments provide opportunities for various e-commerce to grow rapidly in Indonesia. This situation triggers every e-commerce to compete in providing the best shopping experience for its users. Sociolla is one of the e-commerce sites that sell cosmetic products from both national and foreign companies that offers attractive features for its customers. Sociolla invites customers to create content and review beauty products, whereas in general, other e-commerce platforms do not implement similar features (Graham, 2020).

Sociolla was first established in Indonesia in 2015 as an online community that provided beauty and skincare product reviews for marketing purposes. In a short period, Sociolla was able to attract the interest of its customers which placed the platform as e-commerce specializing in the beauty segment with the most visitors, outperforming a well-established beauty segment platform such as Sephora (Iprice, 2021).

The various shopping experiences offered by Sociolla provide satisfaction for its customers shown by repeated purchases or, in other words, developing customer loyalty. Customer loyalty is the main goal in a strategic marketing plan since it brings profitable outcomes for the company (Pratminingsih et al., 2013). Customer loyalty is defined as a positive attitude that customers have towards e-commerce resulting in repetitive shopping behavior (Srinivasan et al., 2002).

Previous studies have shown that convenience in using e-commerce will have a positive impact

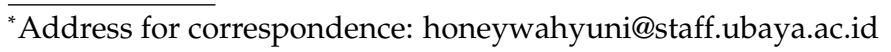




\section{Lilian et all || Product Brokering Efficiency}

on customer loyalty. Ebrahimi et al. (2019) suggested that there is a relationship between online product recommendation (OPR) and customer trust and satisfaction, which eventually lead to customer loyalty. The feature that enables Sociolla customers to review the beauty products is also an example of OPR. H. Zhang et al. (2018) discussed OPR as a type of recommendation provided for customers in online shopping, which contains product recommendations generated by the system as well as recommendations from other customers based on their personal experiences. Recommendations from the system provided by Sociolla will refer to the personal data completed by each Sociolla customer which includes problems experienced by the customers and physical data such as skin type, hair type, etc. Meanwhile, recommendations from fellow customers are shared based on personal use by each customer.

Markopoulos and Clemons (2013) explained that recommendations can assist customers in improving their decision - making process, in addition to reducing the costs or information search efforts. OPR has two roles, i.e., as an enabler and inhibitor. Enabler plays the role of a reinforcer in the decision - making process. Enabler recommendations consist of self-reference and vividness, which are beneficial to improve customer decision - making process (H. Zhang et al., 2018). Tam and Ho $(2005,2006)$, described self-referenced recommendations as suggestions constructed by articulating the customer needs, shopping strategies, and personal references, whereas vividness recommendations are provided in the form of a complete and concrete description of a product. Clear and attractive information displayed by e-commerce can provide customers with complete information about the product and make them involved in the product evaluation process. This way, the optimal quality of decision-making will be achieved (Lim et al., 2000).

On the other hand, inhibitor recommendations serve as barriers to the customer's decision making process. Inhibitor recommendations consist of deceptiveness and information overload $(\mathrm{H}$. Zhang et al., 2018). Deceptiveness is described as a method to persuade customers by presenting information that is inconsistent with reality. Meanwhile, information overload is a condition when customers receive information that is excessive and irrelevant to the product or service (Jacoby et al., 1974). Information overload will make customers tend to make a more effortful evaluation and the shopping process becomes inefficient.

Based on T. Zhang et al. (2011) study, OPR can play a role in customer loyalty through product brokering efficiency (PBE) as a mediator. PBE is a stage of the decision - making, screening, and product evaluation processes when customers make a purchase. PBE consists of two dimensions, i.e., perceived decision effort and perceived decision quality (Ratchford, 2001; T. Zhang et al., 2011). Perceived decision effort is a process of filtering information and evaluating products that are carried out before the purchasing decision is made; whereas perceived decision quality is a form of decision - making quality that is perceived by customers after the purchase. The quality of decision - making is the extent to which the goods that the customers have decided to purchase are meeting their needs or preferences. Xu et al. (2014) found that PBE can reduce customers' cognitive efforts in purchasing decisions, which will have an impact on improving the quality of their decision - making.

As described earlier, enabler is a recommendation that can provide clarity of information about 


\section{Lilian et all || Product Brokering Efficiency}

a product that matches customer preferences. In other words, enabler recommendations can assist customers in deciding on purchase by reducing costs or efforts in selecting information related to the product they want to buy ( $\mathrm{H}$. Zhang et al., 2018). Therefore, it can be concluded that the recommendations of the enabler can reduce the customer's perceived decision effort. This is in line with the research conducted by Jiang and Benbasat (2007a, 2007b) which found that clarity of information on the recommendations of a product will be able to help customers understand the product more clearly, which will also trigger customers to be involved in the product evaluation process.

Product recommendations can effectively articulate customers' personal needs and shopping strategies (Tam \& Ho, 2006), and thus, provide a similar picture as their references. This will cause customers to agree with the recommendations and can reduce customers' cognitive efforts in making decisions. In the study conducted by Senecal et al. (2005), it was found that online product recommendations will make customers spend more effort in shopping, which motivates customers to read several recommendations and compare them with each other. Furthermore, perceived decision quality is one aspect of PBE which refers to the quality of decision making perceived by the customers after making a purchase. Customers with optimal decision - making quality tend to make repeated purchases until customer loyalty is built (T. Zhang et al., 2011). The comprehensible enabler recommendations will motivate customers to be more involved in information processing and can increase customer understanding of the product (Jiang \& Benbasat, 2007a, 2007b). Customers who receive enabler recommendations will be interested in examining the information and comparing it with their personal references. However, this will cause customers to spend more time evaluating the product recommendations (T. Zhang et al., 2011). Considerations made during a thorough product search will improve the quality of customer decision - making. The role of OPR as an inhibitor is to hinder the customer's decision - making process (H. Zhang et al., 2018). As previously described, there are two conditions in inhibitor,i.e., deceptiveness and information overload, which will affect the customer purchasing process by leading the customers to make more purchases than what is needed (Cenfetelli \& Schwarz, 2011). The role of this OPR will be related to the perceived decision effort stage which is the customer effort during the online shopping process. Recommendations that are inconsistent with reality will trigger customers to conduct a more thorough evaluation to eliminate irrelevant information.

Deceptiveness will have a negative effect on OPR or society (Fang, 2012). The recommendation process that appears will also be meaningless to customers due to the poor credibility of the recommendations. In addition, information overload presents recommendations that are excessive and disorganized (Lee \& Lee, 2004). When the presented recommendations are irrelevant or inconsistent with reality, then customers will need more effort to achieve optimal decision making (Darke \& Ritchie, 2007). When the customer's perceived decision effort is high, customer loyalty will be affected. The higher the effort required in shopping, the less likely the customers will make repeated purchases. H. Zhang et al. (2018) stated that customers will maximize value in the decision - making process during shopping. For instance, T. Zhang et al. (2011) study showed that high perceived decision 


\section{Lilian et all || Product Brokering Efficiency}

quality in PBE increased customer loyalty. This is because the perceived decision quality as a form of the decision - making process after making a purchase will be positively correlated to repurchase intentions. Meanwhile, the role of OPR as an inhibitor is to persuade and motivate the customers to shop without a clear intent and purpose. In addition, this type of recommendation tends to display much irrelevant information and makes it difficult to find products, which makes customers become overwhelmed in filtering information, which eventually results in low decision - making quality (Park \& Lee, 2008). If the quality of the shopping decision-making process is poor, then customers are less likely to return to shop at the e-commerce.

Based on the elaboration of problems above, this study adopts four hypotheses with Figure 1 depicts conceptual framework of this study:

1. H1: There is a correlation between enabler in online product recommendation and customer loyalty with perceived decision effort in product brokering efficiency as a mediator for Sociolla customers.

2. H2: There is a correlation between enabler in online product recommendation and customer loyalty with perceived decision quality in product brokering efficiency as a mediator for Sociolla customers.

3. H3: There is a correlation between inhibitors in online product recommendation and customer loyalty with perceived decision effort in product brokering efficiency as a mediator for Sociolla customers.

4. H4: There is a correlation between inhibitors in online product recommendation and customer loyalty with perceived decision quality in product brokering efficiency as a mediator for Sociolla customers.

\section{Figure 1}

Research Framework

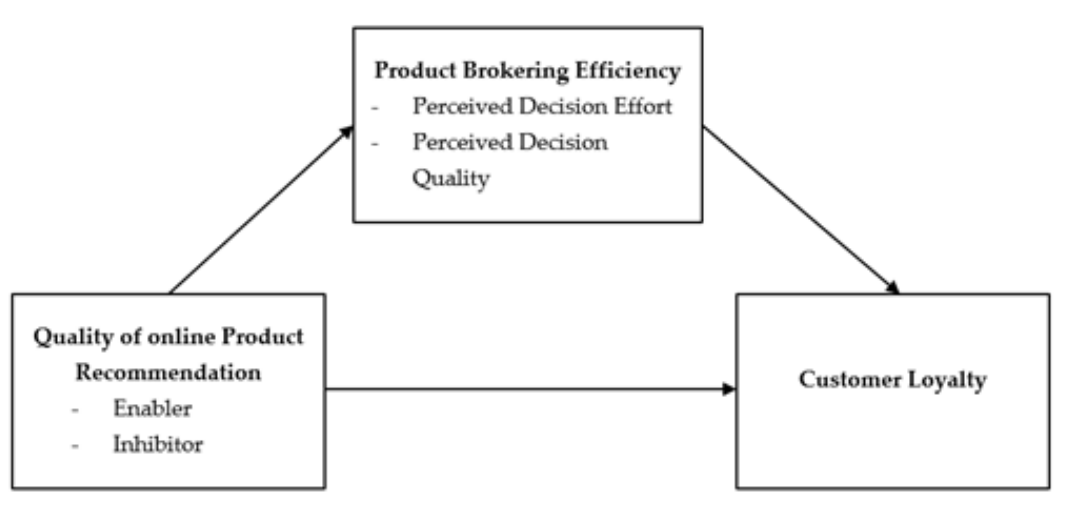




\section{Lilian et all || Product Brokering Efficiency}

\section{Method}

\section{Participants}

The participants in this study were 179 Sociolla customers ( 7 males and 172 females) who have at least 1-time shopping experience at Sociolla, with the age ranging from 18 to 25 years old (Mean = 20.7, SD = 1.35). Participant demographic data of this study are presented in Table 1 which consists of employment status, marital status, duration of knowing Sociolla, duration of using Sociolla, frequency of purchasing at Sociolla in a month, frequency of using the Sociolla application/website in a week, and the advantages of Sociolla. The majority of participants in this study were students (82.1\%) who are unmarried (98.3\%). On average, 104 people (58.1\%) have known Sociolla for 1-2 years, but most participants have only been Sociolla users for an average of 1-2 years (81.6\%). In addition, on average, the majority of the participants shop at Sociolla 1-3 times a month (94.4\%) and as many as 131 people (72.8\%) will visit the Sociolla application or website for 1-2 hours within a week. Furthermore, the majority of participants considered that the advantage of Sociolla is that it sells original products (45.2\%) and provides reviews (30.3\%) (note: each participant could provide more than one response).

Table 1

Demographic data $(N=179)$

\begin{tabular}{|c|c|c|c|}
\hline Demographic & Group & Frequency & $\begin{array}{c}\text { Percentage } \\
(\%)\end{array}$ \\
\hline \multirow[t]{2}{*}{ Job status } & Employee & 32 & 17.9 \\
\hline & Student & 147 & 82.1 \\
\hline \multirow[t]{2}{*}{ Marital status } & Unmarried & 176 & 98.3 \\
\hline & Married & 3 & 1.7 \\
\hline \multirow[t]{3}{*}{ Sociolla } & $>4$ years & 14 & 7.8 \\
\hline & 3-4 years & 61 & 34.1 \\
\hline & $1-2$ years & 104 & 58.1 \\
\hline \multirow[t]{3}{*}{ Sociolla } & $>4$ years & 5 & 2.8 \\
\hline & 3-4 years & 28 & 15.6 \\
\hline & $1-2$ years & 146 & 81.6 \\
\hline \multirow{4}{*}{$\begin{array}{l}\text { purchases at Sociolla } \\
\text { (within } 1 \text { month) }\end{array}$} & $>9$ times & 3 & 1.7 \\
\hline & 7-9 times & 1 & .6 \\
\hline & 4-6 times & 5 & 2.8 \\
\hline & 1-3 times & 170 & 94.4 \\
\hline
\end{tabular}




\section{Lilian et all || Product Brokering Efficiency}

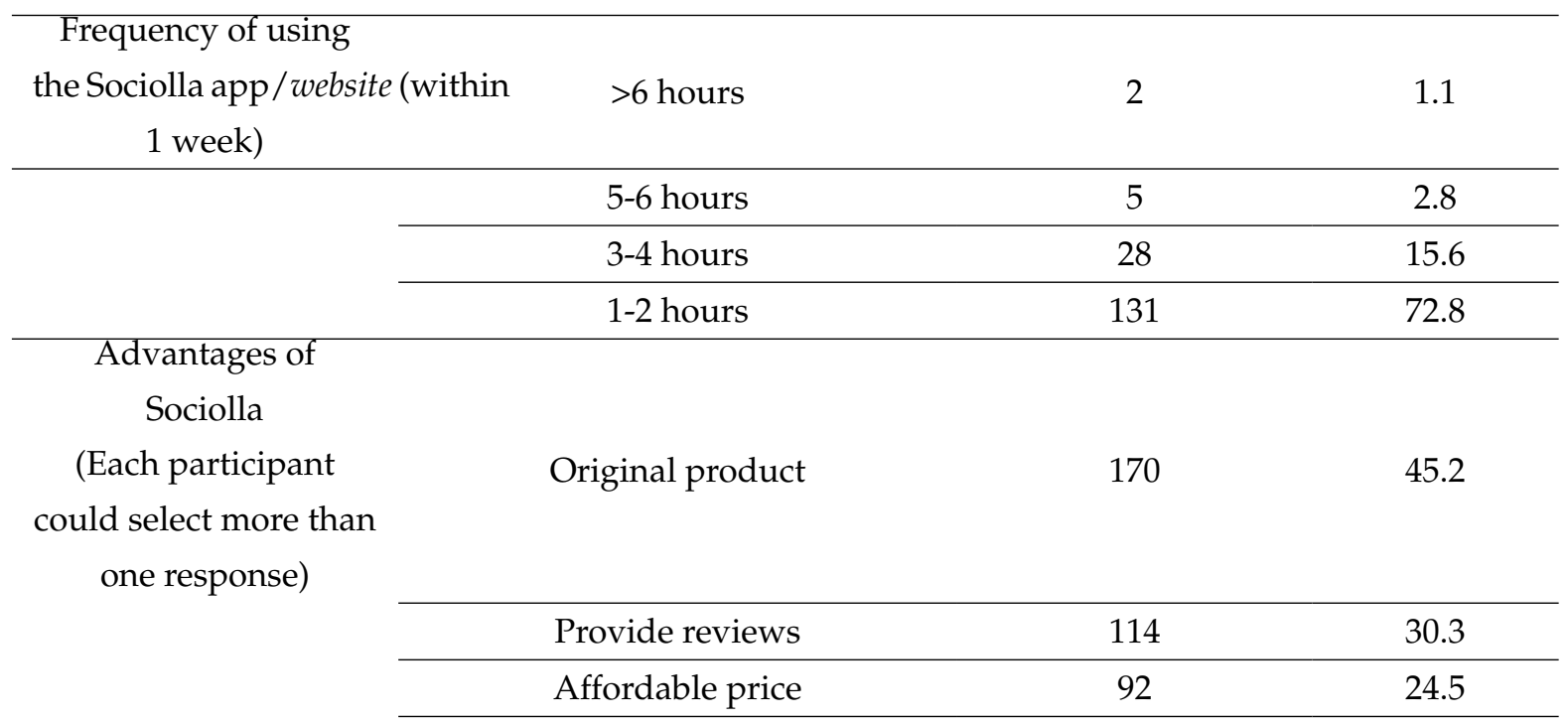

\section{Data Collection}

Data collection was carried out between 26 and 28 October 2020 by distributing questionnaires viaGoogle Form following the Indonesian government's health protocol in response to the COVID-19 pandemic situation. The authors used convenience sampling, which is a technique of determining samples by chance that meets the criteria of the research that has been determined (Sugiyono, 2009). The google form link was distributed through various social media platforms such as Instagram, WhatsApp, Line, and Twitter, including to the authors' colleagues and the Sociolla user community.

The customer loyalty measure used in this study was developed by Zeithaml et al. (1996) which consisted of 5 items on a 7 Likert scale $(1=$ very unlikely to $7=$ very likely), with Cronbach's alpha coefficient of 0.83 . For example, one item in this measure stated: "Recommend Sociolla to people asking for advice". This measure was used as the items were considered appropriate to measure the customer loyalty variable.

Online product recommendation was measured using H. Zhang et al. (2018) scale in which each of the enabler and inhibitor dimensions consisted of 7 items on 7 Likert scale ( $1=$ strongly disagree to 7 = strongly agree), with Cronbach's alpha coefficients of.83 (enabler) and 77 (inhibitor). An example for enabler item includes "I feel that the products at Sociolla match my preferences"; whereas the inhibitor dimension includes items such as "Information about product recommendations varies".

Product brokering efficiency was also measured using a scale developed by $\mathrm{H}$. Zhang et al. (2018) which consisted of 6 items for perceived decision effort and 3 items for perceived decision quality on 7 Likert scale $(1=$ strongly disagree to $7=$ strongly agree), with Cronbach's alpha coefficient of 0.77 perceived decision effort and .78 perceived decision quality. An example of items on perceived decision effort includes "It's easy for me to find the items I want at Sociolla", while an example of items on perceived decision quality includes "I have chosen a product that suits my taste at Sociolla. 


\section{Lilian et all || Product Brokering Efficiency}

\section{Data analysis}

The data analysis was conducted using SPSS - PROCESS HAYES model 4 with a 95\% confidence interval level and the number of bootstrap samples is 5000 .

\section{Result}

Table 2 presents correlational analyses to test the relationship between online product recommendation (enabler and inhibitor) and product brokering efficiency (effort and quality) customer loyalty.

Table 2

Correlations between online product recommendation, product brokering efficiency, and customer loyalty

\begin{tabular}{lccccc}
\hline Variable & $\mathbf{1}$ & $\mathbf{2}$ & $\mathbf{3}$ & $\mathbf{4}$ & $\mathbf{5}$ \\
\hline Customer loyalty & & $.63^{* *}$ & -.07 & $-.15^{*}$ & $.67^{* *}$ \\
Online product recommendation (Enabler) & & & $-.17^{*}$ & -.14 & $.59^{* *}$ \\
Online product recommendation (Inhibitor) & & & & $.52^{* *}$ & -.15 \\
Product brokering efficiency (Effort) & & & & & $-.26^{* *}$ \\
Product brokering efficiency (Quality) & & & & & \\
\hline
\end{tabular}

${ }^{* *} p<.01 ;{ }^{*} p<.05$

Based on the results shown in Table 2, it can be concluded that enabler in the online product recommendation was positively correlated with customer loyalty $(\mathrm{r}=.63, \mathrm{p}<.01)$, while the inhibitor dimension in this variable was not significantly correlated with customer loyalty $(r=-.07, p>.05)$. However, product brokering efficiency on both effort $(\mathrm{r}=-.15, \mathrm{p}<.05)$ and quality $(\mathrm{r}=.67, \mathrm{p}<.01)$ dimensions were positively correlated with customer loyalty.

Hypothesis testing was then carried out using SPSS 21.0 Process Hayes model 4 to determine the role of the mediator in four separate analyses. The bootstrapped value on the indirect effect can determine the role of the mediator on the relationship between the dependent variable and the independent variable (Preacher \& Hayes, 2008). The confidence interval value can be declared significant if the confidence interval value does not exceed zero. The following are the results of the hypothesis testing:

Table 3

Hypothesis testing results 1

\begin{tabular}{ccccccccc}
\hline $\mathbf{X}$ & $\mathbf{M}$ & $\mathbf{R}^{2}$ & \multicolumn{3}{c}{ total effect } & \multicolumn{2}{c}{ direct effects } & \multicolumn{2}{c}{ Indirect Effect } \\
\cline { 2 - 9 } & $\beta$ & $95 \% \mathrm{CI}$ & $t$ & $\beta$ & $95 \% \mathrm{CI}$ & $t$ & $\beta$ & $95 \% \mathrm{CI}$ \\
\hline \multirow{2}{*}{$\mathrm{EN}^{\mathrm{b}}$ PBE-E. 54} & .45 & $.37 ;$ & \multirow{2}{*}{$10.8^{* * *} \mathrm{a}$} & .25 & $.16 ;$ & \multirow{2}{*}{$5.59^{* * * a}$} & .002 & $.01 ;$ \\
\hline
\end{tabular}

${ }^{\mathrm{a}} p<.001{ }^{\mathrm{b}}$ Enabler ${ }^{\mathrm{c}}$ Product Brokering Efficiency - Effort ${ }^{\mathrm{d}}$ Customer Loyalty

As shown in Table 3, it was found that there was no mediator role of product brokering efficiency (PBE) - perceived decision effort on the correlation between enabler (OPR) and customer loyalty. The results of the first hypothesis test are indicated by the value of $\beta=.002$, SE 


\section{Lilian et all || Product Brokering Efficiency}

$=.006$, CI $(-.01 ; .01)$, indicating that hypothesis 1 is rejected. Enabler was significantly correlated with product brokering efficiency - perceived decision effort $(\beta=-.16, p<.05)$. Product brokering efficiency - perceived decision effort was not significantly correlated with customer loyalty $(\beta=-.01, p$ $>$.05). Meanwhile, enabler was significantly correlated with customer loyalty $(\beta=.25, \mathrm{p}<.001)$.

Table 4

Hypothesis testing results 2

\begin{tabular}{|c|c|c|c|c|c|c|c|c|c|c|}
\hline \multirow[t]{2}{*}{$X$} & \multirow[t]{2}{*}{$\mathbf{M}$} & \multirow[t]{2}{*}{$\mathbf{R}^{2}$} & \multicolumn{3}{|c|}{ total effect } & \multicolumn{3}{|c|}{ direct effects } & \multicolumn{2}{|c|}{ Indirect Effect } \\
\hline & & & $\beta$ & $95 \% \mathrm{CI}$ & $t$ & $\beta$ & $95 \% \mathrm{CI}$ & $t$ & $\beta$ & $95 \% \mathrm{CI}$ \\
\hline $\mathrm{EN}^{\mathrm{b}}$ & PBE-Q ${ }^{c}$ & .54 & .45 & $\begin{array}{l}.37 \\
.53\end{array}$ & $10.8^{* * * a}$ & .25 & $\begin{array}{l}.16 \\
.34\end{array}$ & $5.59^{* * * a}$ & .20 & $\begin{array}{l}.13 \\
.27\end{array}$ \\
\hline
\end{tabular}

${ }^{\mathrm{a}} \mathrm{p}<.001{ }^{\mathrm{b}}$ Enabler ${ }^{\mathrm{c}}$ Product Brokering Efficiency - Qualityd Customer Loyalty

From Table 4, it can be seen that there is a mediator role of product brokering efficiency (PBE) - perceived decision quality in the relationship between enabler (OPR) and customer loyalty. The results of this analysis show the value of $\beta=.20, \mathrm{SE}=.03, \mathrm{CI}(.13 ; .27)$, which means that hypothesis 2 is accepted. Enabler was significantly correlated with product brokering efficiency - perceived decision quality $(\beta=.28, \mathrm{p}<.05)$. Product brokering efficiency-perceived decision quality was significantly correlated with customer loyalty $(\beta=.69, \mathrm{p}<.05)$. Meanwhile, enabler was significantly correlated with customer loyalty $(\beta=.25, \mathrm{p}<.001)$. These results indicate that partial mediation occurred in this model.

Table 5

Hypothesis test results 3

\begin{tabular}{|c|c|c|c|c|c|c|c|c|c|c|}
\hline \multirow[t]{2}{*}{$X$} & \multirow[t]{2}{*}{$\mathbf{M}$} & \multirow[t]{2}{*}{$\mathbf{R}^{2}$} & \multicolumn{3}{|c|}{ total effect } & \multicolumn{3}{|c|}{ direct effects } & \multicolumn{2}{|c|}{ Indirect Effect } \\
\hline & & & $\beta$ & $95 \% \mathrm{CI}$ & $t$ & $\beta$ & $95 \%$ CI & $t$ & $\beta$ & $95 \% \mathrm{CI}$ \\
\hline $\mathrm{IN}^{\mathrm{b}}$ & PBE-E $^{c}$ & .45 & .05 & $\begin{array}{c}-.15 \\
.06\end{array}$ & .93 & .02 & $\begin{array}{c}-\quad .07 ; \\
.11\end{array}$ & .37 & .003 & $\begin{array}{c}-.05 \\
.06\end{array}$ \\
\hline
\end{tabular}

${ }^{\mathrm{a}}$ p. $001{ }^{\mathrm{b}}$ Inhibitor ${ }^{\mathrm{c}}$ Product Brokering Efficiency - Effort ${ }^{\mathrm{d}}$ Customer Loyalty

The results of hypothesis testing 3 shown in Table 5 illustrate that there is no role of mediator of product brokering efficiency (PBE)- perceived decision effort in the relationship between inhibitors (OPR) and customer loyalty. The results of the third hypothesis test show the value of $\beta=.003, \mathrm{SE}=0.03, \mathrm{CI}(-.05 ; .06)$, indicating that hypothesis 3 is rejected. Inhibitor was significantly correlated with product brokering efficiency-perceived decision effort $(\beta=.58, p<.05)$. Product brokering efficiency - perceived decision effort was not significantly correlated with customer loyalty $(\beta=.005, p>.05)$. Similarly, inhibitor was not significantly correlated with customer loyalty $(\beta=.02, \mathrm{p}>.05)$. 


\section{Lilian et all || Product Brokering Efficiency}

Table 6

Hypothesis test results 4

\begin{tabular}{ccccccccccc}
\hline $\mathbf{X}$ & $\mathbf{M}$ & $\mathbf{R}^{2}$ & \multicolumn{4}{c}{ total effect } & \multicolumn{2}{c}{ direct effects } & \multicolumn{2}{c}{ Indirect Effect } \\
\cline { 3 - 10 } & & $\beta$ & $95 \% \mathrm{CI}$ & $t$ & $\beta$ & $95 \% \mathrm{CI}$ & $t$ & $\beta$ & $95 \% \mathrm{CI}$ \\
\hline \multirow{2}{*}{$\mathrm{IN}^{\mathrm{b}}$} & \multirow{2}{*}{$\mathrm{PBE}^{\mathrm{N}} \mathrm{Q}^{\mathrm{c}}$} & .45 & .05 & .06 & .93 & .02 & .11 & .37 & .07 & .01 \\
\hline
\end{tabular}

${ }^{\mathrm{a}} \mathrm{p}<.001{ }^{\mathrm{b}}$ Inhibitor ${ }^{\mathrm{C}}$ Product Brokering Efficiency - Quality ${ }^{\mathrm{d}}$ Customer Loyalty

Table 4. explains that there is no mediator role of product brokering efficiency (PBE)- perceived decision quality on the relationship between inhibitors (OPR) and customer loyalty. The results of the fourth hypothesis test show the value of $\beta=-.07, \mathrm{SE}=.05$, CI $(-.17 ; .01)$, so that hypothesis 4 is rejected. Inhibitors have an insignificant relationship with product brokering efficiency - perceived decision quality $(\beta=.07, p>.05)$. Product brokering efficiency - perceived decision quality has a significant relationship with customer loyalty $(\beta=1.01, \mathrm{p}<.05)$. While inhibitors have no significant relationship with customer loyalty $(\beta=.02, \mathrm{p}>.05)$.

\section{Discussion}

This study examined and explained the relationship between online product recommendation and customer loyalty, with the mediator online product brokering efficiency on Sociolla customers. Therefore, four hypotheses were conducted, i.e., H1: There is a correlation between enabler in online product recommendation and customer loyalty with perceived decision effort in product brokering efficiency as a mediator for Sociolla customers. H2: There is a correlation between enabler in online product recommendation and customer loyalty with perceived decision quality in product brokering efficiency as a mediator for Sociolla customers. H3: There is a correlation between inhibitors in online product recommendation and customer loyalty with perceived decision effort in product brokering efficiency as a mediator for Sociolla customers. H4: There is a correlation between inhibitors in online product recommendation and customer loyalty with perceived decision quality in product brokering efficiency as a mediator for Sociolla customers.

The results of this study highlighted several important findings. First, the online product recommendation (OPR) - enabler was negatively correlated with product brokering efficiency - effort but was positively correlated with product brokering efficiency - quality. On the other hand, online product recommendation (OPR) - inhibitor was positively correlated with product brokering efficiency - effort but was not correlated with product brokering efficiency - quality. These findings suggest that the recommendations that can meet customer needs should present information that is comprehensive and clear to affect the efforts needed by customers in selecting information and the quality of the products purchased (Lim et al., 2000). In contrast, recommendations that are excessive or less useful for customers will require more efforts to ensure the product to be purchased and it will not affect the quality of the product purchased (H. Zhang et al., 2018). 


\section{Lilian et all || Product Brokering Efficiency}

Second, product brokering efficiency - effort was not correlated with customer loyalty, while product brokering efficiency - quality was positively correlated with customer loyalty. Therefore, out of the four hypotheses tested in this study, only one hypothesis was accepted, which is the role of product brokering efficiency - quality significantly mediated the relationship between online product recommendation - enabler and customer loyalty. When Sociolla provides recommendations or reviews related to certain products, customers will develop trust toward the recommendations and may feel satisfied with the quality of the products that have been purchased (the product matches their needs or preferences and is satisfying). Moreover, this motivates customers to return to repurchase until becoming loyal to the company (H. Zhang et al., 2018; T. Zhang et al., 2011). In online product recommendation - enabler, the recommendations provided are more personal and have higher accuracy as these recommendations can meet the customer needs (Liang et al., 2006; Tam \& Ho, 2005, 2006). In previous studies found that the match between the recommendations and the customer characters as well as a clear and structured delivery of recommendations will affect the perception of a product quality, which in turn will make customers interested in buying Hess et al. (2009), Jiang and Benbasat (2007a), Xu et al. (2014).

On the contrary, the excessive information and various persuasive messages (often done as a form of marketing) conveyed in online product recommendation - inhibitors, will trigger customers to doubt the accuracy or honesty of the information (Craig et al., 2012; H. Zhang et al., 2018). Customers' doubts about persuasive information are often interpreted as a form of manipulation (deceptiveness) which will ultimately affect the revenue/sales (shops/sellers) (Mavlanova et al., 2016; Olbrich \& Holsing, 2011; Wang et al., 2016). The seller's reputation is also an important concern in assessing a recommendation; if the seller's reputation is poor, then the form of recommendation provided is considered as a form of manipulation to push customers to buy the product ( $\mathrm{H}$. Zhang et al., 2018). Based on the demographic data in this study, 114 participants suggested that the strength of Sociolla lies in product reviews provided in the platform, which may describe both the advantages and disadvantages of the products that the customers used. The reason behind the lack of correlation between online product recommendation - inhibitor and product brokering efficiency could be due to the information provided being considered less credible, redundant, and irrelevant, thus causing the customers unable to make decisions when making purchases, which ultimately failed in motivating the customers to become loyal (Darke \& Ritchie, 2007; Lee \& Lee, 2004; Park \& Lee, 2008).

Previous studies suggested that customer loyalty can occur due to product brokering efficiency - perceived decision effort and perceived decision quality (Ratchford, 2001; H. Zhang et al., 2018). However, in this study, product brokering efficiency - perceived decision effort was not correlated with customer loyalty. T. Zhang et al. (2011) suggest that product brokering efficiency perceived decision effort made by customers to analyze the products to be purchased or the costs to be incurred, is entirely under the control of customers will not influence customer loyalty. Customers will decide to stop the product brokering efficiency - perceived decision effort when too many recommendations are received. Based on the demographic data, it can be seen that 131 participants visited the Sociolla website and searched for 1-2 hours within a week. This indicates that participants 


\section{Lilian et all || Product Brokering Efficiency}

can control the product brokering efficiency - perceived decision effort on the product they are interested to buy (by evaluating the product quality to product price).

\section{Conclusion}

Findings from this study suggest that customer loyalty can be formed when the information or recommendations provided by e-commerce (Sociolla) are complete, clear, and can meet customer needs. In addition, the quality of the product purchased must be consistent with the information provided, which in turn will develop customers' trust toward the recommendations. However, when the information provided is too excessive or too persuasive, it will make customers feel cheated and further make customers avoid the buying process. This study results can provide a new understanding of the role of a recommendation or information provided by e-commerce on the formation of customer loyalty.

\section{Recommendations}

Nevertheless, there is a limitation to this study. The research was only focused on one e-commerce (Sociolla), and thus, it may not be possible to generalize that all e-commerce platforms have the same situation and conditions. Additionally, Sociolla also offers content creation to customers that other e-commerce platforms do not provide, which means that Sociolla has its uniqueness that distinguishes the platform from other e-commerce in general. Future studies may replicate this research by taking into account the characteristics of e-commerce in Indonesia in general to investigate the formation of customer loyalty in Indonesian e-commerce.

\section{Declarations}

\section{Acknowledgments}

The authors would like to thank the University of Surabaya and Sociolla users for providing assistance in data collection.

\section{Funding}

The author did not get funding for this research

\section{Authors' contributions}

First author designed this research, first and second authors did the writing and data analysis, and all authors read and agreed with the results of this manuscript.

\section{Conflict of interest}

The author declares that there is no potential conflict of interest in this study 


\section{Lilian et all || Product Brokering Efficiency}

Orcid id

Honey Wahyuni https:/ / orcid.org/0000-0002-0875-1613

\section{References}

Cenfetelli, R. T., \& Schwarz, A. (2011). Identifying and testing the inhibitors of technology usage intentions. Information Systems Research, 22(4), 808-823. https: / / doi.org / 10.1287 / isre.1100. 0295

Craig, A. W., Loureiro, Y. K., Wood, S., \& Vendemia, J. M. (2012). Suspicious minds: Exploring neural processes during exposure to deceptive advertising. Journal of Marketing Research, 49(3), 361-372. https://doi.org/10.1509/jmr.09.0007

Darke, P. R., \& Ritchie, R. J. (2007). The defensive consumer: Advertising deception, defensive processing, and distrust. Journal of Marketing Research, 44(1), 114-127. https: / / doi org / 10. 1509/jmkr.44.1.114

Ebrahimi, A., Sevinç, K., Sevinç, G. G., Cribbs, A. P., Philpott, M., Uyulur, F., Morova, T., Dunford, J. E., Göklemez, S., Arı, Ş., Oppermann, U., \& Önder, T. T. (2019). Bromodomain inhibition of the coactivators CBP/EP300 facilitate cellular reprogramming. Nature Chemical Biology, 15(5), 519-528. https://doi.org/10.1038/s41589-019-0264-z

Fang, Y. H. (2012). Does online interactivity matter? Exploring the role of interactivity strategies in consumer decision making. Computers in Human Behavior, 28(5), 1790-1804. https: / / doi.org/ 10.1016/j.chb.2012.04.019

Graham, L. (2020). Keuntungan berbelanja online di Sociolla [The advantages of shopping online at Sociolla]. Retrieved August 24, 2021, from http: / / www. fermeloiedor. com / keuntunganberbelanja-online-di-sociolla/

Hess, T., Fuller, M., \& Campbell, D. (2009). Designing interfaces with social presence: Using vividness and extraversion to create social recommendation agents. Journal of the Association for Information Systems, 10(12), 889-919. https:/ / doi.org/10.17705/1jais.00216

Iprice. (2021). Peta e-commerce Indonesia. https://iprice.co.id/insights/mapofecommerce/

Jacoby, J., Speller, D. E., \& Kohn, C. A. (1974). Brand choice behavior as a function of information load. Journal of Marketing Research, 11(1), 63. https:/ / doi.org/10.2307/3150994

Jiang, Z., \& Benbasat, I. (2007a). Investigating the influence of the functional mechanisms of online product presentations. Information Systems Research, 18(4), 454-470. https:/ / doi.org/10.1287/ isre.1070.0124

Jiang, Z., \& Benbasat, I. (2007b). The effects of presentation formats and task complexity on online consumers' product understanding. MIS Quarterly, 31(3), 475-500. https:// doi.org/10.2307/ 25148804 


\section{Lilian et all || Product Brokering Efficiency}

Lee, B. K., \& Lee, W. N. (2004). The effect of information overload on consumer choice quality in an on-line environment. Psychology and Marketing, 21(3), 159-183. https:/ / doi.org/10.1002/mar. 20000

Liang, T. P., Lai, H. J., \& Ku, Y. I. (2006). Personalized content recommendation and user satisfaction: Theoretical synthesis and empirical findings. Journal of Management Information Systems, 23(3), 45-70. https:/ / doi.org/10.2753/MIS0742-1222230303

Lim, K. H., Benbasat, I., \& Ward, L. M. (2000). The role of multimedia in changing first impression bias. Information Systems Research, 11(2), 115-136. https://doi.org/10.1287/isre.11.2.115.11776

Markopoulos, P. M., \& Clemons, E. K. (2013). Reducing buyers' uncertainty about taste-related product attributes. Journal of Management Information Systems, 30(2), 269-299. https:/ / doi.org/10.2753/ MIS0742-1222300210

Mavlanova, T., Benbunan-Fich, R., \& Lang, G. (2016). The role of external and internal signals in E-commerce. Decision Support Systems, 87, 59-68. https://doi.org/10.1016/j.dss.2016.04.009

Olbrich, R., \& Holsing, C. (2011). Modeling consumer purchasing behavior in social shopping communities with clickstream data. International Journal of Electronic Commerce, 16(2), 15-40. https://doi.org/10.2753/JEC1086-4415160202

Park, D. H., \& Lee, J. (2008). eWOM overload and its effect on consumer behavioral intention depending on consumer involvement. Electronic Commerce Research and Applications, 7(4), 386-398. https://doi.org/10.1016/j.elerap.2007.11.004

Pratminingsih, S. A., Lipuringtyas, C., \& Rimenta, T. (2013). Factors Influencing Customer Loyalty Toward Online Shopping. International Journal of Trade, Economics and Finance, 4(3), 104-110. https:/ / doi.org/10.7763/ijtef.2013.v4.268

Preacher, K. J., \& Hayes, A. F. (2008). Asymptotic and resampling strategies for assessing and comparing indirect effects in multiple mediator models. Behavior Research Methods, 40(3), 879-891. https:/ / doi.org/10.3758/brm.40.3.879

Ratchford, B. T. (2001). The economics of consumer knowledge: Table 1. Journal of Consumer Research, 27(4), 397-411. https://doi.org/10.1086/319617

Senecal, S., Kalczynski, P. J., \& Nantel, J. (2005). Consumers' decision-making process and their online shopping behavior: A clickstream analysis. Journal of Business Research, 58(11), 1599-1608. https: //doi.org/10.1016/j.jbusres.2004.06.003

Srinivasan, S. S., Anderson, R., \& Ponnavolu, K. (2002). Customer loyalty in E-Commerce: An exploration of its antecedents and consequences. Journal of Retailing, 78(1), 41-50. https: / / doi.org/10.1016/S0022-4359(01)00065-3

Sugiyono. (2009). Alfabeta.

Tam, K. Y., \& Ho, S. Y. (2005). Web personalization as a persuasion strategy: An elaboration likelihood model perspective. Information Systems Research, 16(3), 271-291. https:/ / doi.org/10.1287/isre. 1050.0058 


\section{Lilian et all || Product Brokering Efficiency}

Tam, K. Y., \& Ho, S. Y. (2006). Understanding the impact of web personalization on user information processing and decision outcomes. MIS Quarterly, 30(4), 865-890. https: / / doi.org/10.2307/ 25148757

Wang, W., Qiu, L., Kim, D., \& Benbasat, I. (2016). Effects of rational and social appeals of online recommendation agents on cognition- and affect-based trust. Decision Support Systems, 86, 48-60. https://doi.org/10.1016/j.dss.2016.03.007

Xu, J., Benbasat, I., \& Cenfetelli, R. T. (2014). The nature and consequences of trade-off transparency in the context of recommendation agents. MIS Quarterly, 38(2), 379-406. https:// doi.org/10. 25300/MISQ/2014/38.2.03

Zeithaml, V. A., Berry, L. L., \& Parasuraman, A. (1996). The behavioral consequences of service quality. Journal of Marketing, 60(2), 31. https:/ / doi.org/10.2307/1251929

Zhang, H., Zhao, L., \& Gupta, S. (2018). The role of online product recommendations on customer decision making and loyalty in social shopping communities. International Journal of Information Management, 38(1), 150-166. https:/ / doi.org/10.1016/j.ijinfomgt.2017.07.006

Zhang, T., Agarwal, R., \& Jr, H. C. L. (2011). The value of it-enabled retailer learning: Personalized product recommendations and customer store loyalty in electronic markets. MIS Quarterly, 35(4), 859-881. https://doi.org/10.2307/41409964 